\title{
Mechanisms of lung toxicity induced by biomass burning aerosols
}

\author{
Michal Pardo ${ }^{{ }^{*}}$ D, Chunlin Li ${ }^{1}$, Quanfu He ${ }^{1}$, Smadar Levin-Zaidman², Michael Tsoory ${ }^{3}$, Qingqing Yu ${ }^{4,5}$, \\ Xinming Wang ${ }^{4,5,6}$ and Yinon Rudich ${ }^{1}$
}

\begin{abstract}
Background: Carbonaceous aerosols emitted from indoor and outdoor biomass burning are major risk factors contributing to the global burden of disease. Wood tar aerosols, namely, tar ball particles, compose a substantial fraction of carbonaceous emissions, especially from biomass smoldering. However, their health-related impacts and toxicity are still not well known. This study investigated the toxicity of the water-soluble fraction of pyrolyzed wood tar aerosols in exposed mice and lung epithelial cells.
\end{abstract}

Results: Mice exposed to water-soluble wood tar aerosols showed increased inflammatory and oxidative stress responses. Bronchial epithelial cells exposed to the same water-soluble wood tar aerosols showed increased cell death with apoptotic characteristics. Alterations in oxidative status, including changes in reactive oxygen species (ROS) levels and reductions in the expression of antioxidant genes related to the transcription factor Nrf2, were observed and were confirmed by increased levels of MDA, a lipid peroxidation adduct. Damage to mitochondria was observed as an early event responsible for the aforementioned changes.

Conclusions: The toxicity and health effect-related mechanisms of water-soluble wood tar were investigated for the first time in the context of biomass burning. Wood tar particles may account for major responses such as cell death, oxidative stress, supression of protection mechnaisms and mitochondrial damaged cause by expsoure to biomass burning aerosols.

Keywords: Biomass burning, Wood tar particles, Mitochondria, Oxidative stress, Health effects, Inflammation, Apoptosis, Nrf2

\section{Background}

Atmospheric particulate matter (PM) pollution is one of the leading contributors to the global burden of disease [1-4]. Various sources contribute to the global PM load, including biomass burning $[3,5]$, which emits large amounts of gases and particulates into the atmosphere. Burning can be natural or human-induced [6]. Natural sources include wildfires, and global warming scenarios project increases in the frequency and intensity of wildfires [7]. These increases may in turn exert feedback and influence global warming [8]. The annual global mortality from vegetation fire smoke is estimated to be approximately 339,000 deaths/year [9]. However, the implications for public health, such as respiratory, cardiovascular, and other morbidity effects, are still unknown [10].

\footnotetext{
* Correspondence: Michal.levin@weizmann.ac.il

'Department of Earth and Planetary Sciences, Weizmann Institute of Science, 76100 Rehovot, Israel

Full list of author information is available at the end of the article
}

Anthropogenic sources of PM include agricultural operations, industrial processes, and combustion of wood and fossil fuels $[3,5]$. During the winter season, wood combustion is a major source of indoor and outdoor PM pollution in many developed and developing countries. Wood stove cooking, which is prevalent in many countries, also increases indoor exposure to biomass burning smoke [11, 12]. Europe and North America are the regions with the highest proportions of outdoor PM that can be traced to residential heating with solid fuels (approximately $21 \%$ reported in 2010), and approximately 60,000 premature annual deaths are attributed to ambient air pollution from residential heating with wood and coal in these regions $[3,13]$.

Wood smoke particles (WSPs) have been studied to evaluate the hazards of exposure to smoke from biomass burning from both wildfires and home wood-burning stoves [4, 12, 14-16]. Existing evidence links emissions from wood and coal burning to severe health effects such as respiratory and cardiovascular mortality and morbidity 
$[17,18]$. Hazardous exposures result from inhalation of gases and particles that are byproducts and intermediates of the combustion process. Analyses of particles emitted from wood combustion have identified inorganic components (sulfates, nitrates, potassium), organic aerosols (OAs) containing various polyaromatic hydrocarbons (PAHs), and other toxic and carcinogenic contaminants [3, 19-21]. Among biomass burning products, amorphous, carbonaceous particles with typical diameters between ten and hundreds of nanometers have been distinguished as a distinct group; these particles are termed "tar balls" [19-21]. Tar balls constitute considerable fraction of biomass burning carbonaceous aerosols in terms of number and mass concentrations [20, 22].

Toxicological evaluations of ambient PM have been extensively conducted, whereas the toxicology and mechanisms of WSPs and related components have been poorly defined. Recent studies on WSP exposure have suggested that WSPs enhance inflammation and oxidative stress responses [4, 23-27]. The oxidative stress paradigm suggests that low levels of ROS/ oxidative stress can induce antioxidant induction to restore redox homeostasis. When this protection is insufficient, the increased stress can induce other mechanisms such as inflammation. For example, macrophages exposed to wood smoke extract generate free radicals and exhibit lipid peroxidation and an inflammatory response accompanied by activation of nuclear factor kappa B (NF- $k$ B) and release of tumor necrosis factor (TNF)- $\alpha$ [28]. In addition, oxidative stress has been suggested to be mediated by mitochondria since these organelles are both major intracellular sources of reactive oxygen species (ROS) and ROS targets [29], supporting the paradigm of particle toxicity and oxidative stress.

In the last few years, a major effort has been focused on finding associations between specific components in air pollution and human health effects [25, 27, 30-33]. It was previously suggested that the toxicity of WSPs is strongly dependent on the organic fraction and is associated with organic components other than PAHs [25]. Moreover, water-soluble compounds constitute the primary fraction (up to $80 \mathrm{wt. \% )}$ of biomass smoldering smoke particles but have receive less attention than other compounds with regards to their potential toxicological impacts. We hypothesize that the toxicity of biomass burning can be largely attributed to the water-soluble component of wood tar particles.

In this study, we generated wood tar particles from wood pyrolysis and assessed a wide spectrum of toxicity endpoints (overall toxicity and markers for inflammation, oxidative stress and mitochondrial function) in vivo (acute response) in exposed mice and in vitro in human BEAS2B lung epithelial cells. To the best of our knowledge, the toxicity of wood tar in general and of the water-soluble component in particular has not been previously reported.

\section{Results}

Water-soluble wood tar extract characterization and exposure assessment

Wood tar materials were generated by pyrolysis of wood under conditions that simulated the smoldering process. The water-soluble fraction of the wood tar material was extracted to generate an atmospherically relevant wood tar solution. The solution was atomized by a TSI atomizer and then dried to generate a flow of dry particles (Additional file 1: Figure S1). The chemical composition of the particles generated from the extract was qualitatively and quantitatively characterized, as presented in the supporting information (Additional file 1: Figure S1-S2 and Table S1).

Mice (in particular, their heads and noses) were exposed to wood tar aerosols in an individual exposure system (See Additional file 1 for details). The mice were exposed to each concentration of nebulized wood tar aerosols $(2 \mathrm{mg} / \mathrm{ml}$ or $10 \mathrm{mg} / \mathrm{ml})$ for $15 \mathrm{~min}$. The methods for wood tar aerosol exposure assessment and quantification are shown in Additional file 1: Figure S3. The inhaled doses were assessed by monitoring the size distributions of the wood tar aerosols using a scanning mobility particle sizer (SMPS, TSI, MN, USA). Size distribution measurement showed that the particle mass mode diameters ranged from 300 to $400 \mathrm{~nm}$ with a mobility mode diameter of $\sim 200 \mathrm{~nm}$. These particle sizes are similar to those of typical biomass burning and urban environmental pollution aerosols [34, 35]. The calculated inhaled dose for a single exposure for each mouse was $16 \mu \mathrm{g}$ for the $2 \mathrm{mg} / \mathrm{ml}$ initial concentration solution and approximately $677 \mu \mathrm{g}$ for the $10 \mathrm{mg} / \mathrm{ml}$ initial concentration solution (SI).

\section{Inflammatory responses following exposure to wood tar aerosols}

Mice exposed to wood tar aerosols showed increased inflammatory responses, as indicated by increased total cell counts in both bronchoalveolar lavage fluid (BALF) and lung tissue and increased neutrophil, macrophage, and monocyte levels (Fig. 1 and Additional file 1: Figure S4). To confirm the increase in the inflammatory response observed in BALF, the gene expression of interleukin (IL)- $1 \beta$, TNF- $\alpha$, and IL-6, which are inflammatory cytokines involved in PM-induced inflammation, was investigated by real-time PCR $[15,16,31]$. Exposure to aerosols generated from the high-concentration wood $\operatorname{tar}$ solution $(677 \mu \mathrm{g}$ dose $)$ increased the transcript levels of IL-1 $\beta$, TNF- $\alpha$, and IL- 6 (Table 1 and Additional file 1: Figure S5) in lung tissue, whereas exposure to aerosols generated from the low-concentration solution $(16 \mu \mathrm{g}$ dose) increased only the transcription levels of IL-1 $\beta$.

In addition to the in vivo experiments, in vitro experiments were performed in which human lung epithelial 


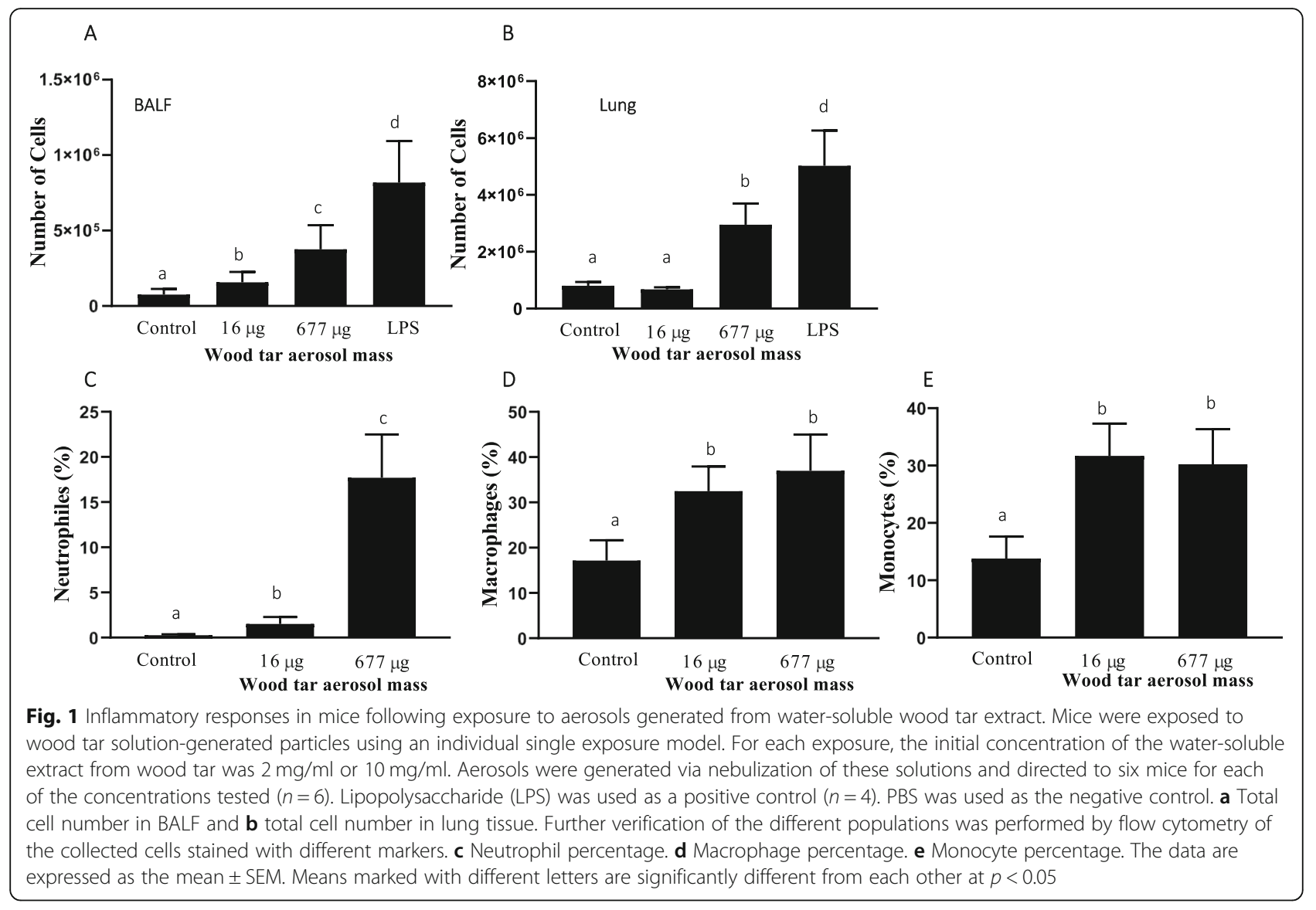

cells (BEAS2B) were exposed to the $2 \mathrm{mg} / \mathrm{ml}$ watersoluble extract of wood tar solution that increased inflammatory gene expression (IL- $1 \beta$, TNF- $\alpha$, and IL-8) (Table 1 and Additional file 1: Figure S6).

\section{Water-soluble wood tar induced cell death in lung epithelial cells}

Five and $24 \mathrm{~h}$ after exposure, approximately 15 and $45 \%$ of the cells stained positive for propidium iodide (PI), respectively, and were considered dead (Fig. 2a) (for the $0.2 \mathrm{mg} / \mathrm{ml}$ concentration). A significant decrease of $55 \%$ in cell viability was observed following $24 \mathrm{~h}$ of exposure to the $2 \mathrm{mg} / \mathrm{ml}$ water-soluble wood tar solution (Fig. 2a-c.). Similarly, a WST-1 assay showed reduced survival after exposure to the wood tar extract (at the same concentration), albeit to a lesser extent, possibly because the PI dye was more sensitive than the WST-1 dye (Additional file 1: Figure S7).

Transmission electron microscopy (TEM) of BEAS2B cells exposed to different concentrations $(0.2 \mathrm{mg} / \mathrm{ml}$ and $2 \mathrm{mg} / \mathrm{ml}$ ) of water-soluble wood tar extract solution at different time points (i.e., 5 and $24 \mathrm{~h}$ ) showed clear changes in the organelles of the exposed cells compared to their controls (Fig. 2d). Prominent changes were observed in the mitochondria. The shapes of the mitochondria in the control cells were heterogeneous, with numerous visible cristae, and the inner and outer mitochondrial membranes appeared intact. Exposure to $0.2 \mathrm{mg} / \mathrm{ml}$ wood tar extract for $5 \mathrm{~h}$ induced marked mitochondrial abnormalities, such as swelling with disarrangement and distortion of cristae. Strikingly, multiple vesicles appeared in the cytosol, and this effect was observed to a greater extent after $24 \mathrm{~h}$ than after $5 \mathrm{~h}$ (Additional file 1: Figure S7). Some of these vesicles could have been remnants of damaged mitochondria. In addition, the nuclei were visible, with evident chromatin condensation. Nevertheless, the outer membranes were not disrupted. All these observations may indicate that the cells were undergoing cell death through apoptosis [36]. Exposure to $2 \mathrm{mg} / \mathrm{ml}$ wood tar extract for $5 \mathrm{~h}$ also induced profound changes in cell structure and permeabilization of the plasma membrane. There were progressive discontinuities that could cause swelling of the cells as well as organelle disruption. Nevertheless, the outer membranes remained intact, suggesting an acute response of cell death (Fig. 2d).

To further characterize the cell death mechanism, cells were stained with annexin $\mathrm{V}$ and 7 -aminoactinomycin $\mathrm{D}$ (7-AAD) to distinguish between the different apoptosis stages (early and late). The proportion of cells in late apoptosis was highest among the wood tar-treated cells, particularly those treated with the $2 \mathrm{mg} / \mathrm{ml}$ concentration 
Table 1 Summary table for biological responses in vivo and in vitro

\begin{tabular}{|c|c|c|c|c|c|c|}
\hline \multirow{2}{*}{ Biological parameter } & \multirow{2}{*}{ Gene } & \multicolumn{3}{|c|}{$\begin{array}{c}\text { In vivo exposure to } \\
\text { wood tar }\end{array}$} & \multicolumn{2}{|c|}{$\begin{array}{c}\text { In vitro exposure (6 } \\
\text { hours) }\end{array}$} \\
\hline & & $\begin{array}{c}2 \\
\mathrm{mg} / \mathrm{ml}\end{array}$ & $\begin{array}{c}10 \\
\mathrm{mg} / \mathrm{ml}\end{array}$ & LPS & $\begin{array}{c}0.2 \\
\mathrm{mg} / \mathrm{ml}\end{array}$ & $2 \mathrm{mg} / \mathrm{ml}$ \\
\hline \multirow{4}{*}{ Inflammatory cytokines } & $\mathrm{I} 11 \beta$ & {$[+]$} & {$[+]$} & {$[+++]$} & & {$[++]$} \\
\hline & Tnf- $\alpha$ & & {$[+]$} & {$[+++]$} & & {$[++]$} \\
\hline & Il6 & & {$[+]$} & {$[+++]$} & & \\
\hline & $\mathrm{I} 18$ & & & & & {$[+]$} \\
\hline \multirow{3}{*}{ Oxidative stress markers } & $\mathrm{OH}-1$ & & {$[+]$} & {$[+]$} & & \\
\hline & MT-2 & {$[+]$} & {$[+]$} & {$[+]$} & & \\
\hline & CYP2E & & {$[+]$} & {$[+]$} & & \\
\hline \multirow{6}{*}{$\begin{array}{c}\text { Protective mechanisms related } \\
\text { to } \mathrm{Nrf} 2\end{array}$} & $\mathrm{Nrf2}$ & & {$[-]$} & {$[--]$} & & {$[-]$} \\
\hline & catalase & & {$[-]$} & {$[--]$} & {$[++]$} & \\
\hline & gpx-1 & & {$[-]$} & {$[-]$} & {$[+]$} & \\
\hline & GSR & & & & & \\
\hline & sod1 & & & & {$[--]$} & {$[--]$} \\
\hline & sod2 & & & & {$[--]$} & [--] \\
\hline \multirow{3}{*}{ Apoptosis-related genes } & $\mathrm{Bax}$ & & & & & {$[+]$} \\
\hline & bcl2 & & & & & \\
\hline & \begin{tabular}{|c|} 
caspase \\
3 \\
\end{tabular} & & & & & {$[+]$} \\
\hline \multicolumn{2}{|l|}{ No statistical difference } & \multicolumn{5}{|c|}{ Not tested } \\
\hline \multicolumn{2}{|l|}{$[+]$ up to 2 -fold increase } & \multicolumn{5}{|c|}{ [-] up to 2-fold decrease } \\
\hline \multicolumn{2}{|l|}{$[++]$ up to 10 -fold increase } & \multicolumn{5}{|c|}{ [- - ] greater than 2-fold decrease } \\
\hline
\end{tabular}

"Pluses and minuses are statistical significance compared to their control

(Fig. 2e). It was found that $0.2 \mathrm{mg} / \mathrm{ml}$ wood tar induced both early and late apoptotic cell death. Apoptosis was also confirmed by the expression of the Bcl-2-associated X protein (BAX; a proapoptotic factor) and caspase-3 genes, which increased after exposure to $2 \mathrm{mg} / \mathrm{ml}$ wood tar extract (Table 1 and Additional file 1: Figure S6).

\section{ROS alterations and oxidative stress after exposure to water-soluble wood tar}

We investigated the potency of the wood tar extract in inducing ROS formation in exposed BEAS2B cells using different probes. Cellular ROS production was evaluated through measurement of dihydrodichlorofluorescein (DCFH) oxidation after $5 \mathrm{~h}$ of exposure. The exposed cells exhibited reduced hydrogen peroxide production capacity (usually considered an indicator of total ROS) (Fig. 3a-b); the hydrogen peroxide levels in the exposed cells were 2 -fold lower than those in the control cells. In addition, dihydroethidium (DHE) oxidation was assessed to detect superoxide anions. In contrast to hydrogen peroxide production, superoxide anion production was increased by the wood tar extracts. This finding may suggest impaired dismutation of superoxide to hydrogen peroxide (Fig. 3c-d).
To further explore the changes in oxidative stress status in vitro and in vivo, real-time PCR analyses for genes that are considered to be markers of oxidative stress and genes that are related to the Nrf2 protection mechanism were performed (Table 1, Additional file 1: Figure S5 and Figure S6). Exposure of BEAS2B cells to the wood tar extracts did not increase any oxidative stress markers but elicited different responses in the expression of genes related to Nrf2. Exposure to the low-concentration $(0.2 \mathrm{mg} / \mathrm{ml})$ wood tar extract increased the expression of Nrf2-related genes such as catalase and glutathione peroxidase-1 (GPx$1)$, whereas exposure to the high-concentration $(2 \mathrm{mg} / \mathrm{ml})$ wood tar extract reduced the expression levels of Nrf2 and catalase. Increases in oxidative stress markers such as heme oxygenase-1 (HO-1), Metallothionein-2 (MT-2) and Cytochrome P450 2E (CYP2E) were observed in mice exposed to water-soluble wood tar aerosols. Genes related to Nrf2 signaling (Nrf2, catalase, and GPx-1) showed reduced levels in mice exposed to wood tar aerosols (Table 1, Additional file 1: Figure S5).

To assess whether the cells were subjected to oxidative stress, the levels of MDA, a lipid peroxidation adduct, were examined after exposure to the wood tar extracts. A minor but significant increase in MDA levels was observed after 


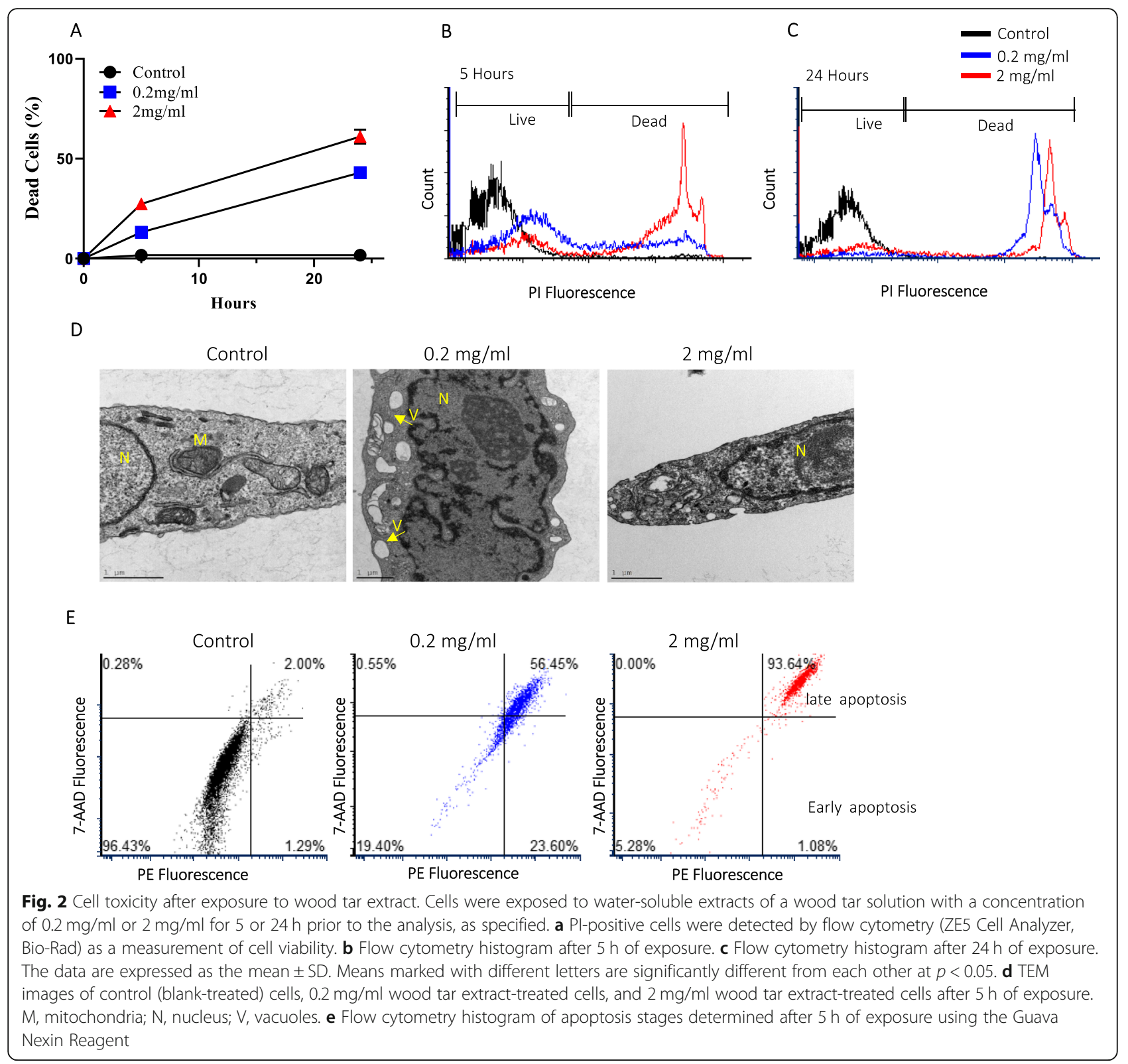

exposure to the $0.2 \mathrm{mg} / \mathrm{ml}$ wood tar extract for both 5 and $24 \mathrm{~h}$. A higher increase in MDA levels was observed after $24 \mathrm{~h}$ of exposure to the $2 \mathrm{mg} / \mathrm{ml}$ wood tar extract (Fig. 3e). In addition, exposure of mice to 16 and $677 \mu \mathrm{g}$ of aerosols from the water-soluble wood tar extract solutions increased lung lipid peroxidation levels in a dose-dependent manner (Fig. 3f).

\section{Water-soluble wood tar damages mitochondria}

Mitochondrial functions were evaluated in BEAS2B cells following exposure to wood tar extracts using a Seahorse analyzer (Fig. 4). As shown in Fig. 4 and the Additional file 1: Figure S8, $5 \mathrm{~h}$ of exposure of BEAS2B cells to wood tar extracts resulted in complete inhibition of the oxygen consumption rate (OCR, red and blue lines) for both concentrations tested (Fig. 4c). This observation further supports the notion that wood tar extracts induce toxicity via mitochondria-related mechanisms.

Cellular metabolism is an important determinant of cell survival and function and comprises oxidative phosphorylation and glycolysis, which are the two main sources of ATP in cells [37]. We therefore measured the glycolysis rate (as the extracellular acidification rate, ECAR) after exposure to wood tar extracts (Fig. 4). ECAR, which reflects glycolysis, was significantly reduced after $5 \mathrm{~h}$ of exposure, indicating that water-soluble wood tar impairs cellular bioenergetics (Fig. 4d). Cellular bioenergetics measurements were also performed after $1 \mathrm{~h}$ of exposure to wood 

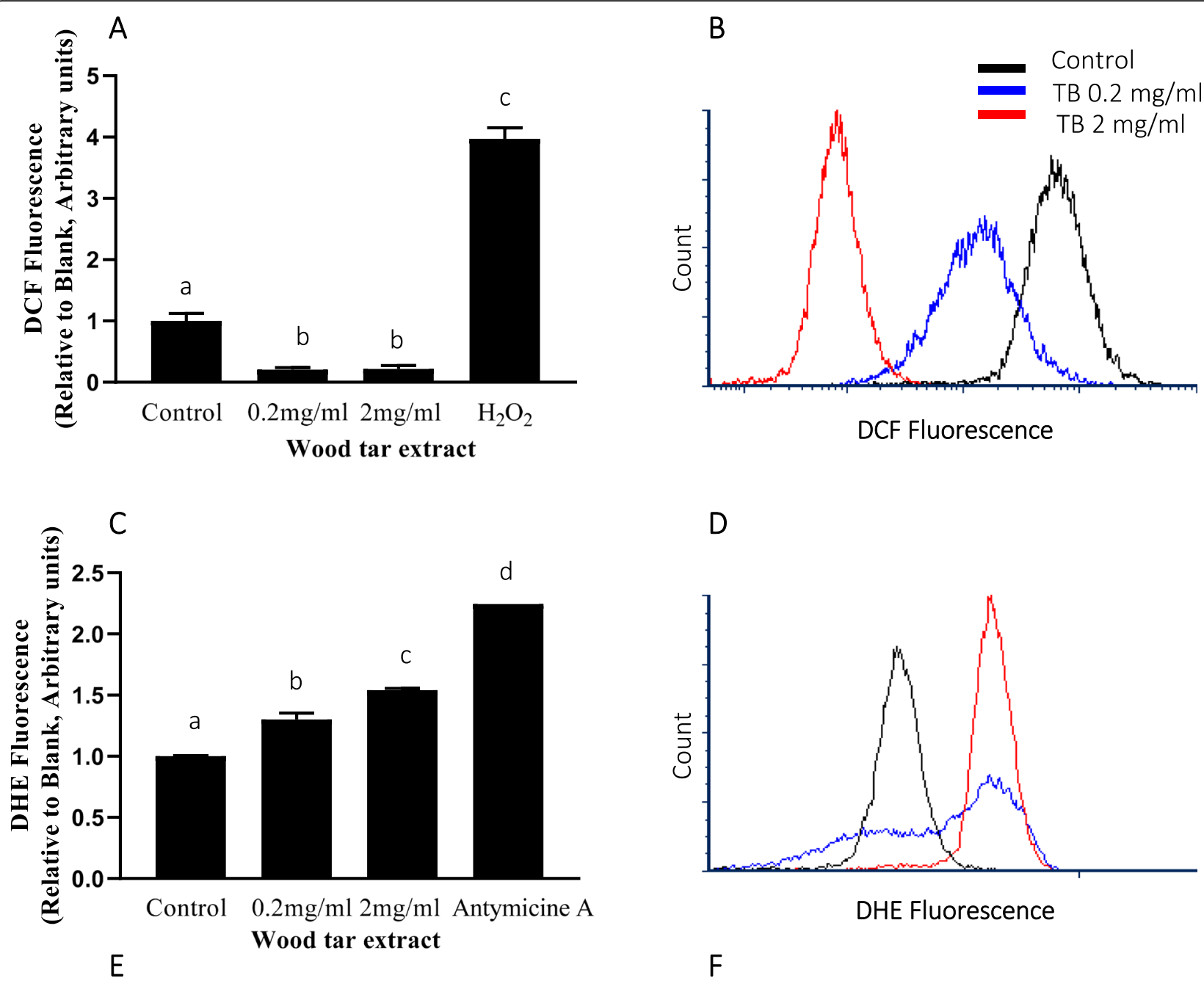

$\mathrm{D}$
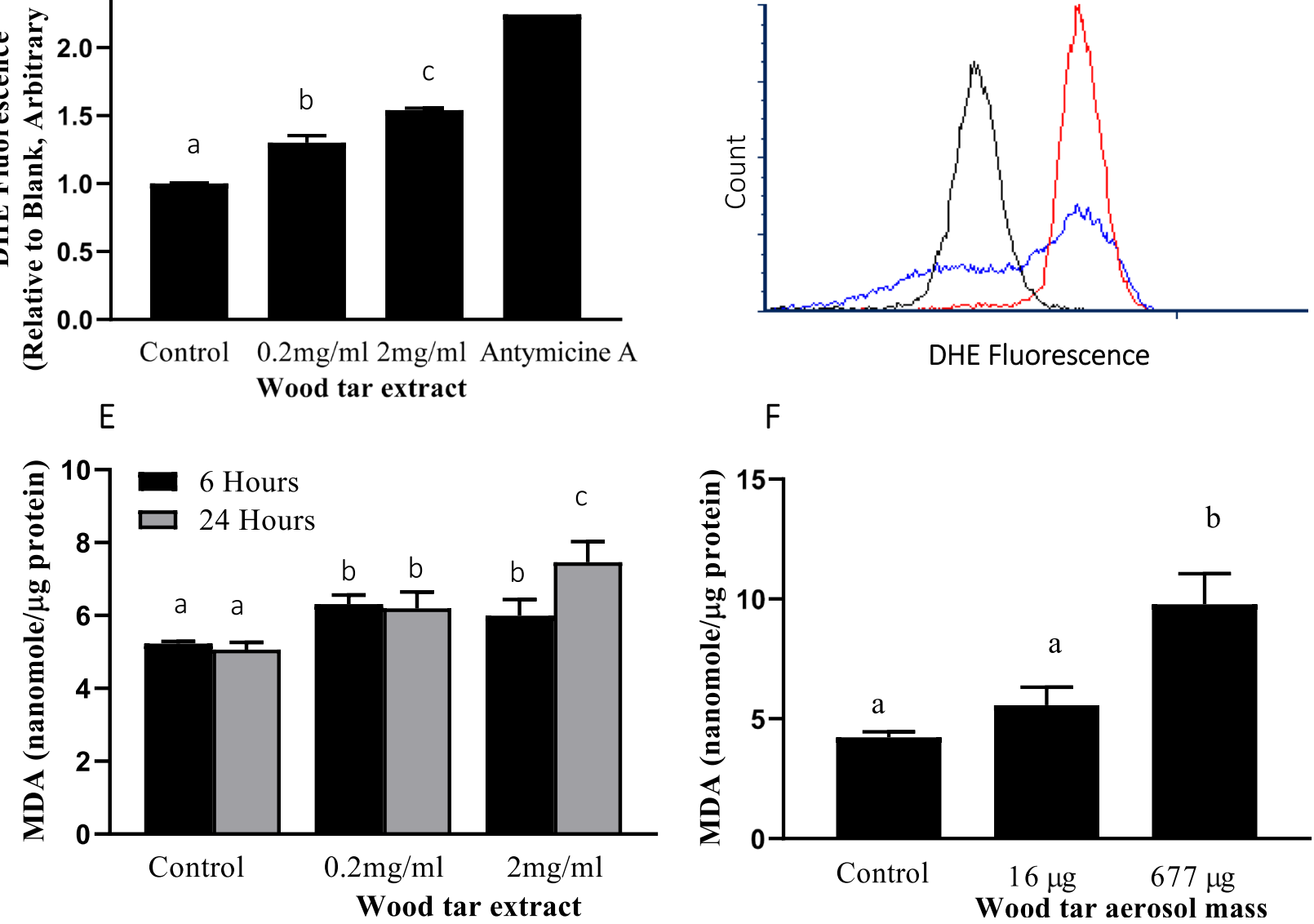

Fig. 3 Oxidative stress after exposure to wood tar extracts. a Intracellular ROS were measured using $\mathrm{H}_{2} \mathrm{DCF}-\mathrm{DA}$, and detection was performed by flow cytometry (ZE5 Cell Analyzer, Bio-Rad). b Flow cytometry histogram for DCF fluorescence. c Superoxide anions were measured using DHE, and detection was performed by flow cytometry (ZE5 Cell Analyzer, Bio-Rad). d Flow cytometry histogram for DHE fluorescence. Lipid oxidation was measured in e cells exposed to wood tar suspension and $\mathbf{f}$ mice exposed to wood tar solution as described in the methods section. The data are expressed as the mean \pm SD. Means marked with different letters are significantly different from each other at $p<0.05$ 


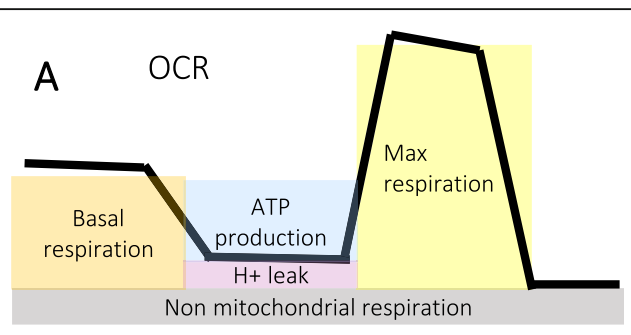

C

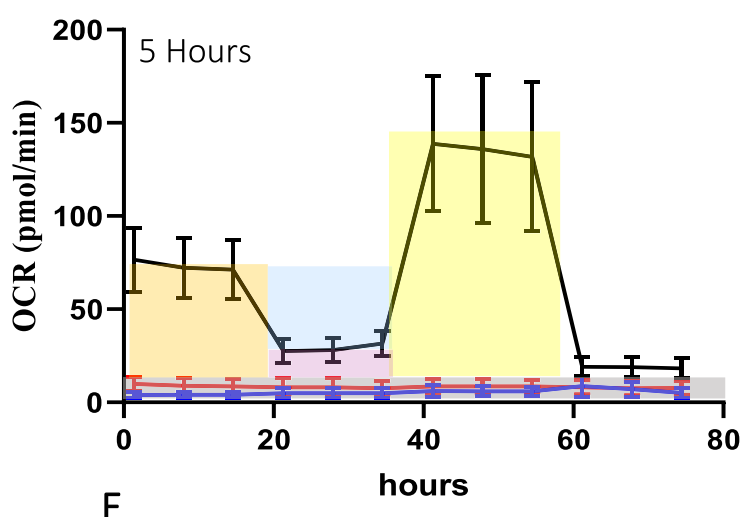

E
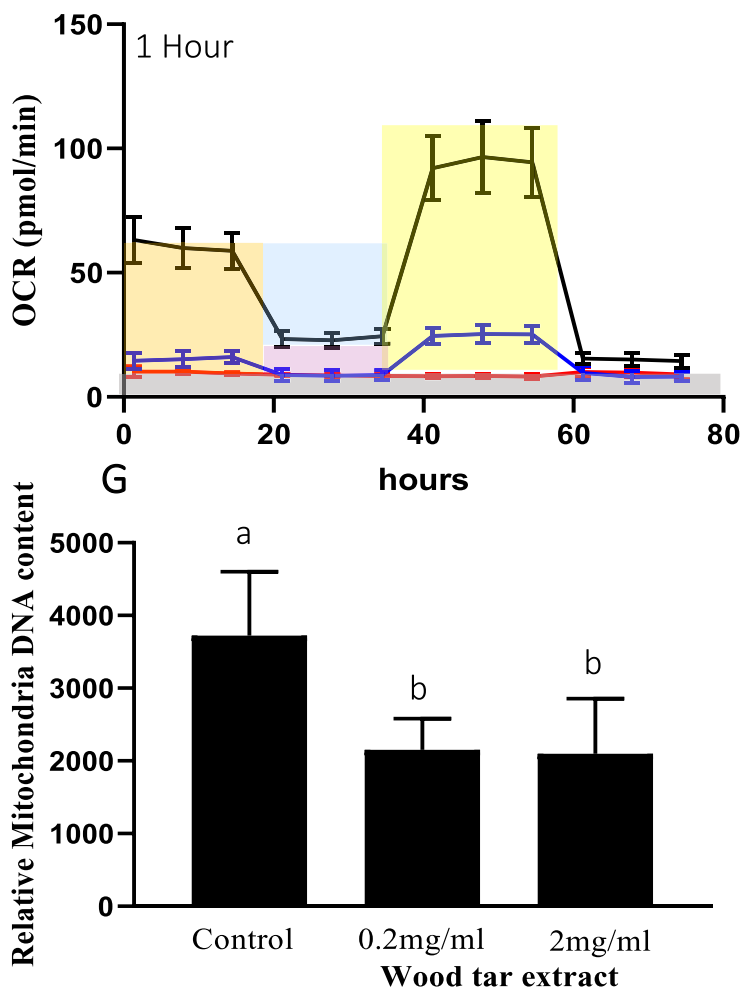
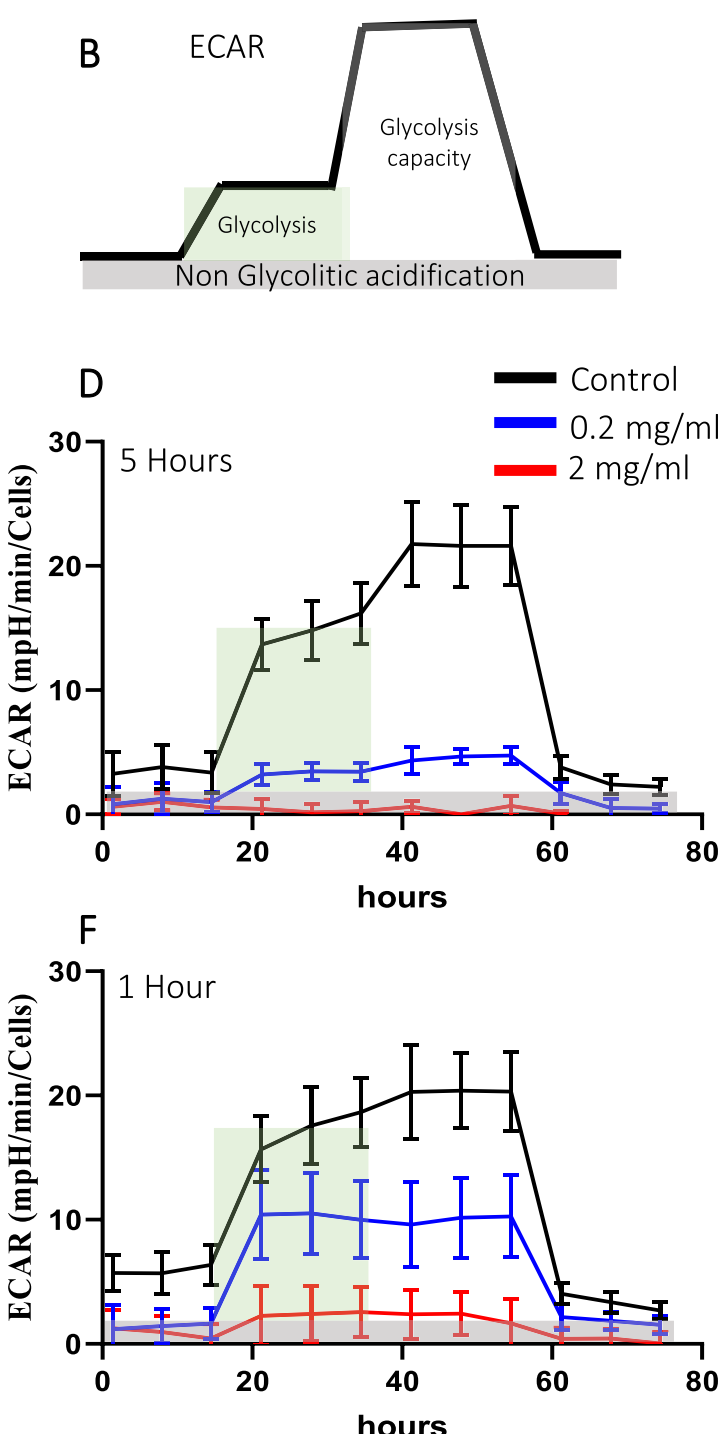

Fig. 4 Mitochondrial response following exposure to wood tar extracts. Cells were exposed to water-soluble extracts from wood tar solution (at a concentration of $0.2 \mathrm{mg} / \mathrm{ml}$ or $2 \mathrm{mg} / \mathrm{ml}$ ) for one or $5 \mathrm{~h}$ prior to analysis, as specified. Determination of the mitochondrial OCR (a measure of mitochondrial respiration) and ECAR (a measure of glycolysis) was performed with a Seahorse analyzer. a Description of the mitochondrial respiration (mitochondrial stress) and $\mathbf{b}$ Seahorse glycolysis assays. Selected results showing $\mathbf{c}$ the basal and mean OCR and $\mathbf{d}$ the basal and mean ECAR following injection of inhibitors and substances after $5 \mathrm{~h}$ of exposure are shown. $\mathbf{e}$ The OCRs after $1 \mathrm{~h}$ of exposure and $\mathbf{f}$ the ECARs after $1 \mathrm{~h}$ of exposure are shown. $\mathbf{g}$ MtDNAcn. The data represent the mean \pm SD. These experiments were performed in triplicate and repeated twice 
tar extracts and revealed significant decreases in both the OCR and the ECAR (Fig. 4e-f).

To further study the influence of wood tar particles on mitochondria, mitochondrial DNA copy numbers (MtDNAcns) were evaluated. Exposure to the wood tar extracts reduced the MtDNAcns by approximately $50 \%$ in BEAS2B cells for both concentrations measured (Fig. 4g).

\section{Discussion}

Wood tar aerosols are typical and abundant particles in biomass burning emissions. In our study, we generated tar aerosols that served as proxies for particles from smoldering carbonaceous materials. The goal of this study was to investigate the acute cytotoxic effects of the water-soluble fraction of a smoldering wood tar solution both in vivo and in vitro. To achieve this goal, we characterized the physical and chemical properties of the generated wood tar extract [19] and exposed mice and lung epithelial cells to this extract.

\section{Wood tar exposure chemical assessment}

Based on our previous and current studies, wood tar aerosols generated by nebulizing the water-soluble extract from pyrolyzed wood are good proxies for atmospheric wood tar particles [19, 20, 38-40]. In this study, the water-soluble wood tar extracts were used in two different concentrations for the in vivo experiments. The calculated inhaled doses (for each mouse) were $16 \mu \mathrm{g}$ and $677 \mu \mathrm{g}$ of dry wood tar particles for the low- and high-concentration extract solutions, respectively. The concentrations used were randomly selected since exposure to wood-burning activity can vary substantially between different households, from day to day or during exposure to wildfire emissions. Consequently, it is difficult to simulate exposures that are relevant on time scales of hours or days. It has previously been suggested that the concentration of tar balls from biomass plumes is approximately $80 \%$ of that of the smoke particles emitted from smoldering biomass close to the source [20], and the concentration decreases with distance and dilution. Additionally, tar ball aggregates compose a significant fraction $(27 \%)$ of samples collected in a plume of the Whitewater-Baldy Complex fire in New Mexico [22]. Therefore, exposure of mice to our conditions for $15 \mathrm{~min}$ is an acute exposure equivalent to days or months of exposure to real biomass burning air pollution according to actual measurements in domestic and field environments [38, 41].

In addition, long term exposure to biomass burning smoke was previously associated with chronic obstructive pulmonary disease (COPD). However, the effects of acute exposures have not been thoroughly studied. Acute exposures as performed in this study suggest possible increased susceptibility to lung disease.

\section{Inflammatory responses after exposure to wood tar aerosols}

Previous studies have indicated that exposure to WSPs in indoor air and from wildfires, burning of biomass and air pollution may impact health $[1,2,4,14,15,27,32$, 42]. It has been shown that WSPs are associated with systemic and pulmonary inflammation [4, 14, 42], as healthy subjects who are exposed develop increased levels of neutrophils in BALF and blood [42]. The results of this study also showed an increased inflammatory response, with increased neutrophil, macrophage and monocyte counts, in exposed mice (Fig. 1).

In addition, an increase in inflammatory gene expression was observed in cells exposed to wood tar extract (Table 1 and Additional file 1: Figure S6). Some in vitro studies on exposure to water-soluble extracts from collected biomass burning particles have also indicated that exposure induces onset of an inflammatory response similar to that observed in our study [4, 28, 43,44], while other studies have shown only a minor inflammatory response following exposure to biomass burning extracts [42, 45, 46]. The combined results from this study suggested that the inflammatory response was increased in both the in vivo and in vitro exposures. However, the inflammatory response appeared milder in the cultured cells than in the mice in vivo expsoure (Table 1 and Additional file 1: Figure S5), suggesting that exposure to wood tar induces a systemic response that is amplified in vivo during exposure.

\section{Cytotoxicity of wood tar to lung epithelial cells}

In vitro studies have demonstrated that biological effects induced by water-soluble extracts from biomass burning particles can generate ROS [46] and induce DNA damage $[15,23,25,46]$. In our study, the acute cytotoxicity of the wood tar extracts (at concentrations of 0.2 and 2 $\mathrm{mg} / \mathrm{ml}$ ) was investigated by using the permeable dye PI, a WST-1 assay and electron microscopy with BEAS2B cells. Exposure to wood tar extracts resulted in cell death in a time- and dose-dependent manner (Fig. 2). These results are supported by a previously published study that showed a decrease in mouse macrophage viability (through PI staining) after exposure to PM1 samples from wood log combustion [15].

Apoptotic cell death is characterized by biochemical events leading to the formation of apoptotic bodies. These bodies are removed by phagocytic cells. Unless these bodies are removed, the cell contents will contact the surrounding cells and damage them by releasing potentially inflammatory intracellular components [47, 48]. Failure of apoptotic cell clearance can lead to late apoptosis (also referred to as secondary necrosis) [47, 48]. Dying cells can be characterized as being in early apoptosis, in which phosphatidylserine is expressed on the cell surface and the plasma membrane remains intact. 
Early apoptotic cells can become late apoptotic cells if the plasma membrane becomes permeabilized [47, 48]. Our results showed that cells exhibited apoptotic characteristics following exposure to the wood tar extract (Fig. 2). The importance of apoptosis in PM toxicity has been previously reported $[49,50]$. Our results suggest that apoptosis occurs after exposure to water-soluble wood tar extracts and may result in oxidative damage. As these results indicate a late apoptosis response, clearance of apoptotic cells is likely delayed or impaired. Our findings are also consistent with those of a previous report [51] indicating that exposure of animals to WSPs increased apoptosis in BALF macrophages and lung tissue.

\section{ROS formation, oxidative stress and mitochondrial damage following exposure to water-soluble wood tar} A central paradigm of particle toxicology, particularly PM pollution toxicology, is formation of ROS that leads to inflammation and other adverse health effects [30, 52]. ROS include the superoxide anion, hydrogen peroxide, and hydroxyl radicals, all of which can react and oxidize different biological targets [29]. In this study, we observed increased superoxide anion concentrations and decreased hydrogen peroxide concentrations after exposure. The decreased oxidation of the DCFH fluorophore following exposure to wood tar extracts could be related to the activity of one or two antioxidant enzymes that prevent accumulation of superoxide in the cytosol (superoxide dismutase [SOD1], $\mathrm{Cu} / \mathrm{ZnSOD}$ ) and in the mitochondria (SOD2, MnSOD). Indeed, decrease in both SOD1 and SOD2 gene expression were observed following exposure to wood tar extract.

Increases in the levels of different ROS species may lead to oxidative stress through disruption of the balance between oxidant and antioxidant molecules, leading to tissue damage (to DNA, lipids and proteins [31, 32, 53](. It has previously been shown that the transcription factor Nrf2 and its related genes are involved in the response to PM exposure [31, 32]. We have suggested that repeated exposures to PM may exhaust the Nrf2 antioxidant defense system, thus leading to oxidative stress. Therefore, the expression of antioxidant genes related to Nrf2 was analyzed by real-time PCR after exposure to wood tar extracts (Table 1, Additional file 1: Figure S5 and Figure S6). Exposure of BEAS2B cells to the highest concentration $(2 \mathrm{mg} / \mathrm{ml})$ of wood tar extracts reduced Nrf2-related gene expression. Wood tar extract at the $0.2 \mathrm{mg} / \mathrm{ml}$ concentration did not reduce Nrf2-related gene expression; on the contrary, it increased the expression of catalase and GPX genes. This finding may imply the induction of protection mechanisms. In addition to the cells, the mice exposed to wood tar aerosols also exhibited reduced levels of phase II protective genes (Table 1, Additional file 1: Figure S5). Taken together, the reductions in SOD enzymes and decreases in phase II protection enzymes related to the Nrf2 pathway following exposure to wood tar extracts may support the notion that the exposure reduced cellular antioxidant capacity.

Accumulation of superoxide in cells is associated with oxidative stress [29]. The cells in this study were subjected to oxidative stress after exposure to wood tar extracts that led to actual oxidative damage (increased MDA levels), particularly the cells exposed to the higher concentration (2 $\mathrm{mg} / \mathrm{ml}$ ). Increased MDA levels was also observed in mice exposed to wood tar. Several other studies have also shown increases in MDA levels after exposure to WSPs; for example, WSPs released during cooking with fuelwood have been found to increase plasma MDA levels in women from northeast India [12]. In addition, following exposure to wood smoke, alveolar MDA levels increase in human subjects [24]. Another study showed that wood smoke generated hydroxyl radicals $(\mathrm{OH})$ and induced MDA formation (lipid peroxidation) [28]. In this study, mild changes in lipid peroxidation were observed and elevated levels of superoxide anion were measured within cells after exposure to the extract. As hydroxyl radicals are thought to be the main radicals responsible for damage, this finding may explain the low levels of lipid peroxidation observed in this study.

Mitochondria are the major cellular sources of ROS, which are generated as byproducts during normal respiration $[26,29,54]$. The alterations in ROS levels, the structural changes in the mitochondria observed using TEM and even the reductions in SOD2 levels may suggest that exposure to water-soluble wood tar can lead to mitochondrial damage. Damage to mitochondria could have been the result or even the cause of the changes in ROS. The mitochondrial damage observed using the Seahorse analyzer following $1 \mathrm{~h}$ of exposure may suggest that mitochondria are organelles that respond early to exposure. This finding may imply that increased ROS levels, alterations in oxidative stress status, and cell death via apoptosis are consecutive events following mitochondrial damage. We have previously shown that exposure of cells to organic extracts containing high PAH levels reduces the rates of cellular bioenergetic processes (both the OCR and the ECAR) [33]. The watersoluble wood tar extracts used in this study had low PAH contents. However, they were more toxic with respect to cellular bioenergetics than the organic extracts from samples from Beijing used in our previous study, which were collected in winter and dominated by PAHs from coal combustion [33].

MtDNAcn can be used as another indicator of mitochondrial damage because it correlates with the size and number of mitochondria in a cell and may change under different cellular energy demands or different physiological or environmental conditions [33, 54]. Recent studies have 
correlated ambient PM exposure with mitochondrial DNA damage [26, 33, 54]. Similar to our study, a previous study found that personal exposure to fine PM and benzo $[a]$ pyrene from indoor air pollution reduced MtDNAcns in leukocytes of women from China [55].

\section{Conclusions}

Biomass burning affects air quality. As a result, outdoor and indoor exposure to biomass burning smoke is an important and growing health risk factor. As previously suggested, the responses induced by the organic fraction of biomass burning smoke are not linked solely to PAH content; rather, they are also associated with other organic compounds [25, 56]. High-resolution aerosol mass spectrometry (HR-AMS), TEM, and Fourier transform infrared spectroscopy (FTIR) results have suggested that wood tar aerosols may serve as proxies for biomass burning aerosols [19]. As found in this study, wood tar aerosols can account for the major responses observed in many studies following exposure to biomass burning particles $[14,15,25]$. Considering all these data, we propose a mechanism of action in which wood tar emissions generated by biomass burning exert toxic effects both in vivo in mice lungs and in vitro in lung cells. Our results suggest that mitochondria play key roles in the early response to wood tar exposure, as mitochondrial function is dramatically reduced immediately following exposure. Damage to mitochondria is also evidenced by reduced MtDNAcns. Consequently, extracts from pyrolyzed wood tar induce oxidative stress and result in cell death by apoptosis in a dose- and time-dependent manner. Cellular homeostasis is also interrupted by reductions in the levels of Nrf2-related protective genes. If cells cannot manage the high concentrations of wood tar and implement protective mechanisms, cell death eventually occurs (Fig. 5).

Notably, the results of the in vivo mouse and in vitro cell exposures in this study may underscore the severity of the health impacts of wood tar extracts, especially considering that the less-polar fraction with greater enrichment of the more-toxic PAHs and their derivatives was not included in our investigation. However, the water-soluble fraction may be more relevant to health, as the particles can be efficiently deposited and dissolved in the respiratory system.

\section{Methods}

\section{Wood tar generation and characterization}

Wood tar was generated and characterized as previously described [19, 39, 40]. Briefly, wood pellets (Hallingdal Trepellets; water content $6.55 \mathrm{wt} . \%$; length $2 \sim 3 \mathrm{~cm}$, diameter $0.2-0.3 \mathrm{~cm}$ ) were pyrolyzed at $550{ }^{\circ} \mathrm{C}$, and the dry distilled tar materials were collected using a water-cooled trap. The water-soluble fraction of the tar materials was extracted with MilliQ water ( $18 \mathrm{M} \Omega$, sterilized by $185 \mathrm{~nm}$ UVA irradiation) and filtered using $0.45 \mu \mathrm{m}$ and $0.2 \mu \mathrm{m}$ syringe filters in sequence (polytetrafluoroethylene [PTFE] membrane, Pall Corporation) to remove impurities and PM. Afterward, the filtered solutions were further centrifuged to remove any suspended colloidal particles $(2500$ rps for $4 \mathrm{~min}$ at $-2^{\circ} \mathrm{C}$ ). Finally, the extracted tar solution was freeze-dried to obtain the water-soluble tar material in a semisolid form. The water-soluble extracts were redissolved and diluted to a $20 \mathrm{mg} / \mathrm{L}$ stock solution using sterilized ultrapure water. Before testing, the chemical compositions of the processed wood tar extracts were extensively characterized using FTIR (Thermo Scientific

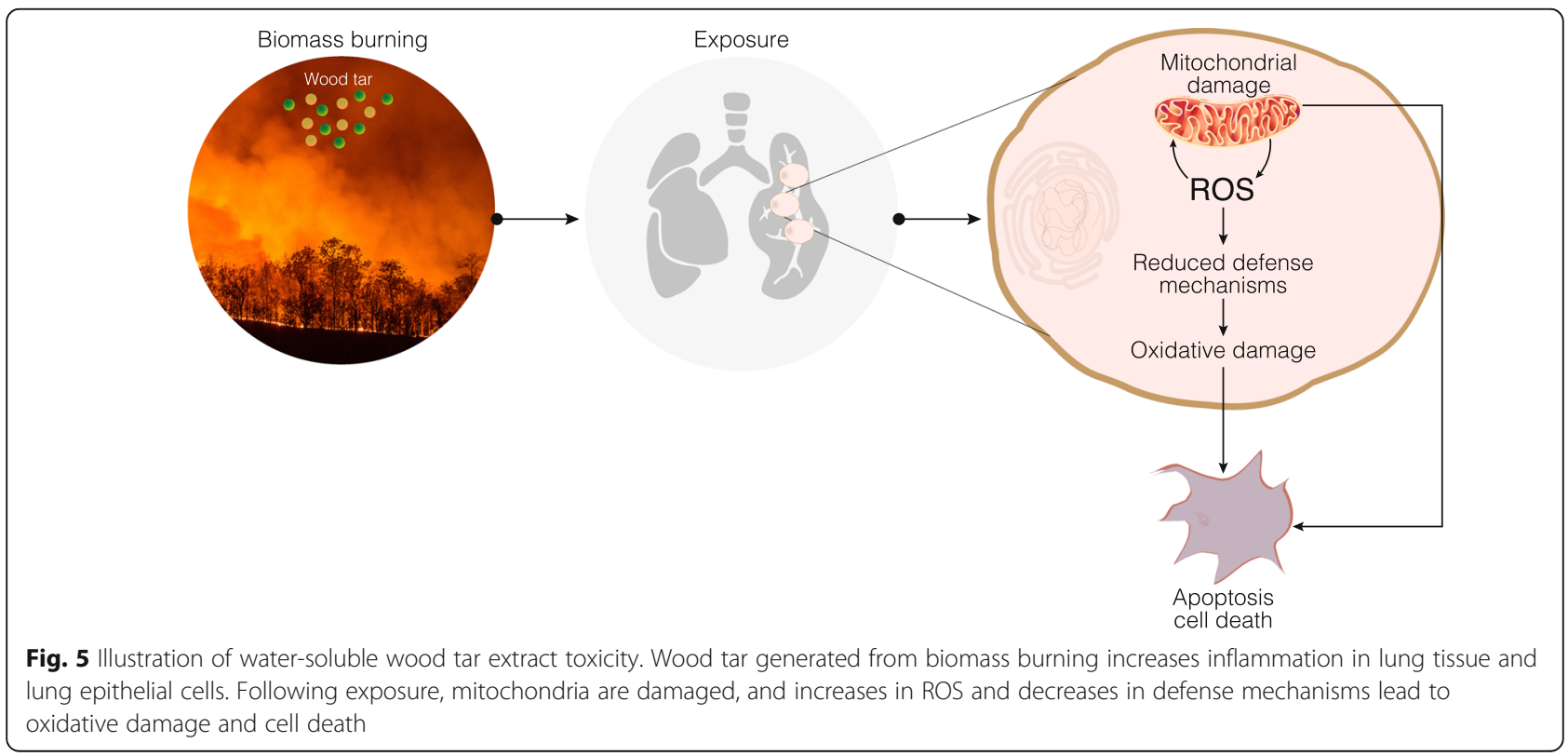


Nicolet 6700) and multiple mass spectrometry applications, e.g., high-resolution time of flight aerosol mass spectrometry (HR-ToF-AMS, Aerodyne) and GC-MS. The detailed measurements and results are given in the Additional file 1: Figure S1 and S2.

\section{In vivo exposure to wood tar aerosols}

The study was approved by the Institutional Animal Care and Use Committee (IACUC) at the Weizmann Institute of Science. Seven-week-old female C57BL/6 mice were purchased from Harlan Laboratories (Rehovot, Israel). One week after arrival, the mice were exposed to the water-soluble tar aerosol. The exposure system used in this study was made of Plexiglas and was divided into six sections for six individual animals. The main inlet was connected to a nebulizer at its top, and the nebulized particles were uniformly distributed throughout the chambers. The outlet of the chamber was connected to a vacuum trap (Additional file 1: Figure S3a). Watersoluble tar extract or phosphate buffer solution (PBS) was aerosolized into the chamber, and the mice were allowed to breathe air containing the aerosol without restraint or anesthesia. PBS Aerosol containing Escherichia coli lipopolysaccharide (LPS) $(0.5 \mathrm{mg} / \mathrm{mL}$; L2630, Sigma) was used as positive control. Complete aerosolization of the solution was achieved in $15 \mathrm{~min}$. The aerosol generation and exposure system was designed to ensure exposure to the head and nose only, with minimal effect on the skin or fur. The mice were exposed once to the tar aerosol using a solution with one of two different initial concentrations: $2 \mathrm{mg} / \mathrm{ml}$ or $10 \mathrm{mg} / \mathrm{ml}$. The details of the exposure assessment, particle size distribution and mass concentrations are described in the Additional file 1: Figure S3. After completion of the respiratory exposure, the mice were returned to their cages.

Twenty-four hours following the exposure, the mice were sacrificed with an overdose of ketamine/xylazine (20 mg/kg and $10 \mathrm{mg} / \mathrm{kg}$ body weight, respectively), and whole-body perfusion with PBS was performed. BALF was extracted as previously described [32]. Briefly, the lungs and tracheas were exposed by dissection, and a tracheal cannula was inserted. The lungs were lavaged with PBS, and the cells were separated by centrifugation. The cells were resuspended in $100 \mu$ l of sterile saline. The lungs and liver were extracted.

\section{Lung homogenate preparation and flow cytometry (FACS) analysis}

Mouse lungs were removed and washed in RPMI medium containing $1 \mathrm{mg} / \mathrm{ml}$ collagenase type $4,0.75 \mathrm{mg} / \mathrm{ml}$ hyaluronidase (Sigma), and $0.02 \mathrm{mg} / \mathrm{ml}$ DNase I (Roche). Then, the lungs were minced, incubated at $37^{\circ} \mathrm{C}$ for 45 min and then filtered through a $100 \mu \mathrm{m}$ cell strainer. Lung cells and BALF cells were suspended in red blood cell lysis buffer and then washed twice with FACS buffer. Conjugated anti-mouse antibodies (CD45-PerpCP, CD11b-PE, F4/80-APC/Cy7, PE/Cy7-CD115 and Ly6G-APC) (BioLegend, San Diego, CA) were used. The samples were washed and analyzed with a ZE5 Cell Analyzer (Bio-Rad). Approximately $10^{4}$ cells were collected from each sample. To identify the different populations, the cells were gated for CD45 and CD11b membrane staining and then gated with for F4/80, CD115 and Ly6G staining (for macrophages, monocytes and neutrophils, respectively). The presented population in percentage is calculated for Macrophages as \%Gated, from Cd45+ \& F4/80, for Monocytes as \%Gated, Cd45+ \& CD115, and for Neutrophils as \%Gated, Cd45+ \& CD11b high \& Ly6G high.

\section{RNA extraction and real-time PCR}

Total RNA was extracted from the lungs using TRI reagent according to the manufacturer's recommendation. Total RNA $(1 \mu \mathrm{g})$ was reverse-transcribed into cDNA using random hexamers (Applied Biosystems, CA, USA). The cDNA samples were amplified using SYBR Green qPCR Mix (Applied Biosystems, CA, USA) in a StepOnePlus real-time PCR system (Applied Biosystems, CA, USA). The relative expression was normalized using the expression levels of $\beta$-actin and HPRT. The PCR data was analyzed using StepOnePlus real-time PCR software V2.3 (Applied Biosystems, CA, USA). The primer sequences are listed in the Additional file 1: Table S2.

\section{Oxidative damage}

Oxidative damage in lung tissue and cell cultures was evaluated by examining lipid peroxidation using the thiobarbituric acid (TBA) method, as previously described [31]. Absorbance was measured in a microplate reader (Bio-Tech Instruments, VT, USA) at $532 \mathrm{~nm}$. A standard curve was created with MDA tetrabutylammonium salt (Sigma-Aldrich, MO, USA).

\section{Cell culture and exposure}

The human lung bronchial cell line BEAS2B (ATCC CRL-9609 ${ }^{\text {min }}$ ) was grown in DMEM (Gibco, Thermo Fisher Scientific, MA, USA) supplemented with 10\% fetal bovine serum (FBS) and $5 \mu \mathrm{g} / \mathrm{ml}$ penicillin/streptomycin (Biological Industries) at $37^{\circ} \mathrm{C}$ in a humidified atmosphere consisting of $95 \%$ air and $5 \% \mathrm{CO}_{2}$.

BEAS2B cells were exposed to wood tar suspension in serum-free medium with salts/glucose; the medium comprised $50 \mathrm{mM}$ HEPES, $100 \mathrm{mM} \mathrm{NaCl}, 5 \mathrm{mM} \mathrm{KCl}, 2$ $\mathrm{mM} \mathrm{CaCl}$, and $5 \mathrm{mM}$ glucose ( $\mathrm{pH} 7.2$ prior to use to maintain osmolarity). The cells were exposed to wood tar suspensions at $0.2 \mathrm{mg} / \mathrm{ml}$ and $2 \mathrm{mg} / \mathrm{ml}$ concentrations and to blank extracts, which underwent the same procedures as the suspensions but with water and were used as controls. The working concentration were 
determined in preliminary tests to set suitable range limits. Cell death was measured after exposure for both 5 and $24 \mathrm{~h}$. However, since a substantial number of cells died within $24 \mathrm{~h}$, all the other assays were performed after $5 \mathrm{~h}$ exposure.

\section{Determination of cell viability and cell death mechanisms} The DNA-intercalating dye PI, which is excluded by viable cells, was used. Flow cytometry analysis (ZE5 Cell Analyzer, Bio-Rad) was used to evaluate cell viability with the following fluorescence settings: excitation (Ex) at $488 \mathrm{~nm}$ and emission $(\mathrm{Em})$ at $610 \mathrm{~nm}$ [57]. The data were collected from 10,000 cells.

In addition, a WST-1 assay was used according to the manufacturer's instructions (Abcam, Cambridge, UK.) Absorbance was measured in a microplate reader (BioTech Instruments, VT, USA) at $440 \mathrm{~nm}$ and $650 \mathrm{~nm}$.

To evaluate the type of cell death, Annexin V (V-PE) and the impermeant dye 7-AAD (Guava Nexin Reagent, Guava Technologies) were used to distinguish between the early/late apoptosis stages and cell death mechanisms. Fluorescence was measured at an Ex of $488 \mathrm{~nm}$ and an Em of $575 \mathrm{~nm}$. The data were collected from 10,000 cells.

\section{TEM analysis}

Cells were fixed with $3 \%$ paraformaldehyde and $2 \%$ glutaraldehyde in $0.1 \mathrm{M}$ cacodylate buffer containing $5 \mathrm{mM}$ $\mathrm{CaCl}_{2}$ (pH 7.4) and then post fixed in $1 \%$ osmium tetroxide supplemented with $0.5 \%$ potassium hexacyanoferrate trihydrate and potassium dichromate in $0.1 \mathrm{M}$ cacodylate for $1 \mathrm{~h}$. The cells were then stained with $2 \%$ uranyl acetate in water for $1 \mathrm{~h}$, dehydrated in graded ethanol solutions and embedded in Agar 100 epoxy resin (Agar Scientific Ltd., Stansted, UK). Ultrathin sections (70-90 $\mathrm{nm}$ ) were viewed and photographed with an FEI Tecnai SPIRIT (FEI, Eidhoven, Netherlands) transmission electron microscope operated at $120 \mathrm{kV}$ and equipped with an EAGLE charge-coupled device (CCD) camera.

\section{Measurement of intracellular ROS}

Following $5 \mathrm{~h}$ of exposure to wood tar suspension, intracellular ROS were detected. For detection with dichlorodihydrofluorescein diacetate $\left(\mathrm{H}_{2}\right.$ DCF-DA), the cells were incubated with $25 \mu \mathrm{M} \mathrm{H} \mathrm{H}_{2}$ DCF-DA for $30 \mathrm{~min}$ at $37^{\circ} \mathrm{C}$. The dichlorofluorescein (DCF) fluorescence was recorded using flow cytometry at an Ex/Em of 488/532 nm [57]. Hydrogen peroxide $\left(\mathrm{H}_{2} \mathrm{O}_{2}\right)$ was used as a positive control. For detection with DHE, the cells were incubated with $25 \mu \mathrm{M}$ DHE for $30 \mathrm{~min}$ at $37^{\circ} \mathrm{C}$ [58]. DHE emission was recorded using flow cytometry with an Ex/Em of 488/575 $\mathrm{nm}[59,60]$. Antimycin A (AA) was used as a positive control. The data were collected from 10,000 cells.

$\mathrm{H}_{2}$ DCF is more specific for hydrogen peroxide than to other ROS since its oxidation depends on intracellular peroxidase activity; thus, $\mathrm{H}_{2} \mathrm{DCF}$ has high reactivity with hydrogen peroxide, lipid hydroperoxide, and hydroxyl radicals and low reactivity with superoxide anions [58, 61]. DHE is a redox-sensitive probe that has been widely used to detect intracellular superoxide anions. The superoxide anion $\left(\mathrm{O}_{2}\right)$ reacts with DHE to form an oxidized product and leads to the enhancement of fluorescence $[59,60]$.

\section{Mitochondrial physiology}

Mitochondrial bioenergetics and function were measured using an XF96 Extracellular Flux Analyzer (Seahorse Bioscience, North Billerica, MA, USA) according to the manufacturer's instructions, as previously described [33]. BEAS2B cells were seeded for $24 \mathrm{~h}$ in specific Seahorse tissue culture plates at a density of $6 \times 10^{4}$ cells/well. Following exposure to wood tar suspension for $5 \mathrm{~h}$, both mitochondrial respiration (measured as the OCR) and glycolysis (measured as the ECAR) were evaluated. The OCR was evaluated after adding $0.5 \mu \mathrm{M}$ oligomycin, $1 \mu \mathrm{M}$ carbonyl cyanide 4-(trifluoromethoxy) phenylhydrazone (FCCP), and $0.5 \mu \mathrm{M}$ rotenone. The ECAR was evaluated after adding $10 \mu \mathrm{M}$ glucose, $1 \mu \mathrm{M}$ oligomycin and $50 \mathrm{mM}$ 2-Deoxy-D-glucose. Both the OCR and the ECAR were normalized to the number of cells per well using Cyquant staining (Thermo Fisher Scientific, Waltham, MA, USA).

\section{MtDNAcn}

DNA extraction was performed with a DNeasy Blood and Tissue Kit (Qiagen). Real-time PCR for human tRNA Leu (UUR) and $\beta 2$-microglobulin, representing mitochondrial and nuclear DNA genes, respectively, was performed as previously described by [62]. The primers used are listed in Additional file 1: Table S1.

\section{Statistical analysis}

The mouse results are expressed as the mean \pm standard error of the mean (SEM). The cell culture results are expressed as the mean \pm standard deviation (SD) of at least three experiments. Differences between two group means were tested by Student's $t$-test, and one-way ANOVA was used for multivariable analyses. Differences were considered significant at a probability level of $p<$ 0.05 using Tukey's honestly significant difference (HSD) test. The statistical analyses were performed and the graphs were generated in GraphPad\#8 software (GraphPad Software, La Jolla, CA, USA).

\section{Supplementary information}

Supplementary information accompanies this paper at https://doi.org/10. 1186/s12989-020-0337-x.

Additional file 1. Figure S1. HR-Tof-AMS spectra for water-soluble wood tar aerosol. Figure S2. FT-IR spectra for water-soluble wood tar 
aerosol. Table S1. Chemical composition of the water-soluble wood tar material analyzed by the GC-MSD. Figure S3. Determination of particle mass concentration in mice exposure system. Figure S4. Mice inflammatory response after exposure to water soluble wood tar aerosol. Figure S5. Cytotoxicity of water-soluble wood tar extract. Figure $\mathbf{S 6 .}$

Mitochondria-response after exposure to water-soluble wood tar extracts. Table S2. List of Mus musculus and Homo sapiens primers.

\section{Abbreviations}

BALF: Bronchoalveolar Lavage Fluid, ${ }_{i}$ CYP2E: Cytochrome P450 2E; ECAR: Extracellular Acidification Rate; GPx-1: Glutathione Peroxidase-1; HO1: Heme Oxygenase-1; IL: Interleukin; MDA: Malondialdehyde; MT2: Metallothionein-2; MtDNAcn: Mitochondrial DNA Copy Number; NFkB: Nuclear Factor Kappa B; OA: Organic Aerosol; OCR: Oxygen Consumption Rate; PAHs: Polyaromatic Hydrocarbons; PM: Particulate Matter; ROS: Reactive Oxygen Species; SMPS: Scanning Mobility Particle Sizer; TEM: Transmission Electron Microscopy; TNF-a: Tumor Necrosis Factor a; WSPs: Wood Smoke Particles

\section{Acknowledgements}

This study is part of the Helmholtz International Lab aeroHEALTH (www. aerohealth.eu). MT is an incumbent of the Carolito Stiftung Research Fellow Chair in Neurodegenerative Diseases.

\section{Authors' contributions}

The manuscript was written by all coauthors. All authors gave approval of the final version of the manuscript. MP designed and performed the experiments, analyzed and interpreted the data, and wrote and revised the manuscript. $\mathrm{CL}$ generated the wood tar and was responsible for the chemical analysis and its interpretation. QH quantified the aerosol flows and mass concentrations and helped with the interpretation of the chemical analysis results. MT designed and constructed the mouse exposure unit. SLZ was involved in the TEM analysis. YR was involved in the design of the study, the writing and the revisions.

\section{Funding}

This research was partially supported by the Israel Science Foundation (ISF) (\#3205/19) and the National Natural Science Foundation of China (NSFC) (Grant No. 41961144029). The work was partially supported by a research grant from the Herbert L. Janowsky Lung Cancer Research Fund, Adam Glickman, Eric Gordon, Alex Rotzang, the David M. Polen Charitable Trust, The Benoziyo Endowment Fund for the Advancement of Science, and the Midwest Electron Microscope Project.

\section{Availability of data and materials}

The datasets supporting the conclusions of this article are included within the article and its additional supplementary files.

\section{Ethics approval and consent to participate}

All animal protocols were approved by the Institutional Animal Care and Use Committee (IACUC) at the Weizmann Institute of Science.

\section{Consent for publication}

$$
\text { Not applicable. }
$$

\section{Competing interests}

The authors declare that they have no competing interests.

\section{Author details}

'Department of Earth and Planetary Sciences, Weizmann Institute of Science, 76100 Rehovot, Israel. ${ }^{2}$ Electron Microscopy Unit, Weizmann Institute of Science, 76100 Rehovot, Israel. ${ }^{3}$ Department of Veterinary Resources, Weizmann Institute of Science, 761001 Rehovot, Israel. ${ }^{4}$ State Key Laboratory of Organic Geochemistry and Guangdong Key Laboratory of Environmental Protection and Resources Utilization, Guangzhou Institute of Geochemistry, Chinese Academy of Sciences, Guangzhou 510640, China. ${ }^{5}$ University of Chinese Academy of Sciences, Beijing 100049, China. ${ }^{6}$ Center for Excellence in Regional Atmospheric Environment, Institute of Urban Environment, Chinese Academy of Sciences, Xiamen 361021, China.
Received: 29 July 2019 Accepted: 6 January 2020

Published online: 20 January 2020

\section{References}

1. Collaborators GBDRF. Global, regional, and national comparative risk assessment of 79 behavioural, environmental and occupational, and metabolic risks or clusters of risks, 1990-2015: a systematic analysis for the global burden of disease study 2015. Lancet. 2016;388(10053):1659-724. https://doi.org/10.1016/S0140-6736(16)31679-8 https:/www.ncbi.nlm.nih. gov/pubmed/27733284.

2. Lelieveld J, Evans JS, Fnais M, Giannadaki D, Pozzer A. The contribution of outdoor air pollution sources to premature mortality on a global scale. Nature. 2015:525(7569):367-71. https://doi.org/10.1038/nature15371.

3. Chafe Z, Brauer M, Héroux M-E, Klimont Z, Lanki T, Salonen RO, et al: Residential heating with wood and coal: health impacts and policy options in Europe and North America. http://www.who.int/iris/handle/10665/153671 (2015).

4. Black C, Tesfaigzi Y, Bassein JA, Miller LA. Wildfire smoke exposure and human health: significant gaps in research for a growing public health issue. Environ Toxicol Pharmacol. 2017;55:186-95. https://doi.org/10.1016/j. etap.2017.08.022 https://www.ncbi.nlm.nih.gov/pubmed/28892756 https:// www.ncbi.nlm.nih.gov/pmc/PMC5628149/.

5. Kim K-H, Kabir E, Kabir S. A review on the human health impact of airborne particulate matter. Environ Int. 2015;74:136-43. https://doi.org/10.1016/j. envint.2014.10.005 http://www.sciencedirect.com/science/article/pii/S016 0412014002992

6. Yadav IC, Devi NL. Biomass Burning, Regional Air Quality, and Climate Change. In Encyclopedia of Environmental Health (Second Edition) (Nriagu, J., Ed.). Oxford: Elsevier; 2019. pp. 386-91.

7. Seidl R, Thom D, Kautz M, Martin-Benito D, Peltoniemi M, Vacchiano G, et al. Forest disturbances under climate change. Nat Clim Chang. 2017;7:395. https://doi.org/10.1038/nclimate3303 https://www.nature.com/articles/ nclimate3303\#supplementary-information.

8. Tubiello FN, Salvatore M, Ferrara AF, House J, Federici S, Rossi S, et al. The contribution of agriculture, forestry and other land use activities to global warming, 1990-2012. Glob Chang Biol. 2015;21(7):2655-60. https://doi.org/10. 1111/gcb.12865 https://onlinelibrary.wiley.com/doi/abs/10.1111/gcb.12865.

9. Cascio WE. Wildland fire smoke and human health. Sci Total Environ. 2018; 624:586-95. https://doi.org/10.1016/j.scitotenv.2017.12.086 http://www. sciencedirect.com/science/article/pii/S004896971733512X.

10. Reid CE, Brauer M, Johnston FH, Jerrett M, Balmes JR, Elliott CT. Critical review of health impacts of wildfire smoke exposure. Environ Health Perspect. 2016;124(9):1334-43. https://doi.org/10.1289/ehp.1409277 https:// www.ncbi.nlm.nih.gov/pubmed/27082891. https://www.ncbi.nlm.nih.gov/ pmc/articles/PMC5010409/

11. Patel S, Leavey A, Sheshadri A, Kumar P, Kandikuppa S, Tarsi J, et al. Associations between household air pollution and reduced lung function in women and children in rural southern India. J Appl Toxicol. 2018:38(11): 1405-15. https://doi.org/10.1002/jat.3659 https:/www.ncbi.nlm.nih.gov/ pubmed/30047157.

12. Rabha R, Ghosh S, Padhy PK. Indoor air pollution in rural north-east India: Elemental compositions, changes in haematological indices, oxidative stress and health risks. Ecotoxicol Environ Saf. 2018;165:393-403. https://doi.org/ 10.1016/j.ecoenv.2018.09.014 http://www.sciencedirect.com/science/article/ pii/S0147651318308546.

13. van der Gon HAC D, Bergström R, Fountoukis C, Johansson C, Pandis SN, Simpson $\mathrm{D}$, et al. Particulate emissions from residential wood combustion in Europe - revised estimates and an evaluation. Atmos Chem Phys. 2015; 15(11):6503-19. https://doi.org/10.5194/acp-15-6503-2015 https:/www. atmos-chem-phys.net/15/6503/2015/.

14. Muala A, Nicklasson H, Boman C, Swietlicki E, Nystrom R, Pettersson E, et al. Respiratory tract deposition of inhaled wood smoke particles in healthy volunteers. J Aerosol Med Pulm Drug Deliv. 2015;28(4):237-46. https://doi.org/ 10.1089/jamp.2014.1122 https:/www.ncbi.nlm.nih.gov/pubmed/25393443.

15. Muala A, Rankin G, Sehlstedt M, Unosson J, Bosson JA, Behndig A, et al. Acute exposure to wood smoke from incomplete combustion--indications of cytotoxicity. Part Fibre Toxicol. 2015;12:33. https://doi.org/10.1186/s12989015-0111-7 https://www.ncbi.nlm.nih.gov/pubmed/26511835.

16. Ferguson MD, Semmens EO, Dumke C, Quindry JC, Ward TJ. Measured pulmonary and systemic markers of inflammation and oxidative stress following Wildland firefighter simulations. J Occup Environ Med. 2016;58(4): 
407-13. https://doi.org/10.1097/JOM.0000000000000688 https://www.ncbi. nlm.nih.gov/pubmed/27058482.

17. Hunter AL, Shah AS, Langrish JP, Raftis JB, Lucking AJ, Brittan M, et al. Fire simulation and cardiovascular health in firefighters. Circulation. 2017;135(14): 1284-95. https://doi.org/10.1161/CIRCULATIONAHA.116.025711 https://www. ncbi.nlm.nih.gov/pubmed/28373523.

18. Hunter AL, Unosson J, Bosson JA, Langrish JP, Pourazar J, Raftis JB, et al. Effect of wood smoke exposure on vascular function and thrombus formation in healthy fire fighters. Part Fibre Toxicol. 2014;11:62. https:/doi.org/10.1186/ s12989-014-0062-4 https://www.ncbi.nlm.nih.gov/pubmed/25487196.

19. Li C, He Q, Schade J, Passig J, Zimmermann R, Meidan D, et al. Dynamic changes in optical and chemical properties of tar ball aerosols by atmospheric photochemical aging. Atmos Chem Phys. 2019;19(1):139-63. https://doi.org/10.5194/acp-19-139-2019 https://www.atmos-chem-phys. net/19/139/2019/.

20. Pósfai M, Gelencsér A, Simonics R, Arató K, Li J, Hobbs PV, et al. Atmospheric tar balls: particles from biomass and biofuel burning. J Geophys Res. 2004;109:D6. https://doi.org/10.1029/2003jd004169 https:// aqupubs.onlinelibrary.wiley.com/doi/abs/10.1029/2003.JD004169.

21. Hueglin C, Gaegauf C, Künzel S, Burtscher H. Characterization of wood combustion particles: morphology, mobility, and photoelectric activity. Environ Sci Technol. 1997;31(12):3439-47. https://doi.org/10.1021/es970139i.

22. Girotto G, China S, Bhandari J, Gorkowski K, Scarnato BV, Capek T, et al. Fractal-like tar ball aggregates from wildfire smoke. Environ Sci Technol Letters. 2018;5(6):360-5. https://doi.org/10.1021/acs.estlett.8b00229.

23. Arif AT, Maschowski C, Garra P, Garcia-Kaufer M, Petithory T, Trouve G, et al. Cytotoxic and genotoxic responses of human lung cells to combustion smoke particles of Miscanthus straw, softwood and beech wood chips. Atmos Environ (1994). 2017;163:138-54. https://doi.org/10.1016/j.atmosenv. 2017.05.019 https://www.ncbi.nlm.nih.gov/pubmed/30519142.

24. Barregard L, Sallsten G, Andersson L, Almstrand AC, Gustafson P, Andersson $M$, et al. Experimental exposure to wood smoke: effects on airway inflammation and oxidative stress. Occup Environ Med. 2008;65(5):319-24. https://doi.org/10.1136/oem.2006.032458 https://www.ncbi.nlm.nih.gov/ pubmed/17704195.

25. Bølling AK, Totlandsdal Al, Sallsten G, Braun A, Westerholm R, Bergvall C, et al. Wood smoke particles from different combustion phases induce similar pro-inflammatory effects in a co-culture of monocyte and pneumocyte cell lines. Part Fibre Toxicol. 2012;9:45. https://doi.org/10.1186/ 1743-8977-9-45 https://www.ncbi.nlm.nih.gov/pubmed/23176191. https:// www.ncbi.nlm.nih.gov/pmc/PMC3544657/.

26. Breton CV, Song AY, Xiao J, Kim S-J, Mehta HH, Wan J, et al. Effects of air pollution on mitochondrial function, mitochondrial DNA methylation, and mitochondrial peptide expression. Mitochondrion. 2019;46:22-9. https://doi. org/10.1016/.j.mito.2019.04.001 http://www.sciencedirect.com/science/ article/pii/S156772491830254X.

27. Yang $M$, Ahmed $H$, Wu W, Jiang B, Jia Z. Cytotoxicity of air pollutant 9,10Phenanthrenequinone: role of reactive oxygen species and redox signaling. Biomed Res Int. 2018;2018:15. https://doi.org/10.1155/2018/9523968.

28. Leonard SS, Wang S, Shi X, Jordan BS, Castranova V, Dubick MA. Wood smoke particles generate free radicals and cause lipid peroxidation, DNA damage, NFkappaB activation and TNF-alpha release in macrophages. Toxicology. 2000;150(1-3):147-57 https://www.ncbi.nlm.nih.gov/pubmed/1 0996671.

29. Schieber M, Chandel NS. ROS function in redox signaling and oxidative stress. Current biology : CB. 2014;24(10):R453-R62. https://doi.org/10.1016/j. cub.2014.03.034 https://www.ncbi.nlm.nih.gov/pubmed/24845678. https:// www.ncbinlm.nih.gov/pme/PMC4055301/

30. Lodovici M, Bigagli E. Oxidative stress and air pollution exposure. J Toxicol. 2011;2011. https://doi.org/10.1155/2011/487074

31. Pardo M, Porat Z, Rudich A, Schauer JJ, Rudich Y. Repeated exposures to roadside particulate matter extracts suppresses pulmonary defense mechanisms, resulting in lipid and protein oxidative damage. Environ Pollut. 2016;210:227-37. https://doi.org/10.1016/j.envpol.2015.12.009 https://www. ncbi.nlm.nih.gov/pubmed/26735168.

32. Pardo $M, X u F$, Qiu X, Zhu T, Rudich $Y$. Seasonal variations in fine particle composition from Beijing prompt oxidative stress response in mouse lung and liver. Sci Total Environ. 2018;626:147-55. https://doi.org/10.1016/.scitotenv.2018. 01.017 http: //www.sciencedirect.com/science/article/pii/S0048969718300172.

33. Pardo M, Xu F, Shemesh M, Qiu X, Barak Y, Zhu T, et al. Nrf2 protects against diverse PM2.5 components-induced mitochondrial oxidative damage in lung cells. Sci Total Environ. 2019;669:303-13. https:/doi.org/10.1016/j.scitotenv. 2019.01.436 https://www.ncbi.nlm.nih.gov/pubmed/30878937.

34. Morawska L, Thomas S, Jamriska M, Johnson G. The modality of particle size distributions of environmental aerosols. Atmos Environ. 1999;33(27):4401-11 https://doi.org/10.1016/S1352-2310(99)00217-4. http://www.sciencedirect. com/science/article/pii/S1352231099002174.

35. Bluvshtein N, Flores JM, He Q, Segre E, Segev L, Hong N, et al. Calibration of a multi-pass photoacoustic spectrometer cell using light-absorbing aerosols. Atmos Meas Tech. 2017;10(3):1203-13. https://doi.org/10.5194/amt-10-12032017 https://www.atmos-meas-tech.net/10/1203/2017/.

36. Burattini S, Falcieri E. Analysis of cell death by Electron microscopy. In: McCall K, Klein C, editors. Necrosis: methods and protocols. Totowa: Humana Press; 2013. p. 77-89.

37. Zhang X, Lan L, Niu L, Lu J, Li C, Guo M, et al. Oxidative stress regulates cellular bioenergetics in esophageal squamous cell carcinoma cell. Biosci Rep. 2017;37(6):BSR20171006. https://doi.org/10.1042/BSR20171006 https:// www.ncbi.nlm.nih.gov/pubmed/29026004. https:/www.ncbi.nlm.nih.gov/ pmc/PMC5725616/.

38. Sedlacek lii AJ, Buseck PR, Adachi K, Onasch TB, Springston SR, Kleinman L. Formation and evolution of tar balls from northwestern US wildfires. Atmos Chem Phys. 2018;18(15):11289-301. https://doi.org/10.5194/acp-18-112892018 https://www.atmos-chem-phys.net/18/11289/2018/.

39. Tóth A, Hoffer A, Nyirö-Kósa I, Pósfai M, Gelencsér A. Atmospheric tar balls: aged primary droplets from biomass burning? Atmos Chem Phys. 2014; 14(13):6669-75. https://doi.org/10.5194/acp-14-6669-2014 https://www. atmos-chem-phys.net/14/6669/2014/.

40. Tóth Á, Hoffer A, Pósfai M, Ajtai T, Kónya Z, Blazsó M, et al. Chemical characterization of laboratory-generated tar ball particles. Atmos Chem Phys. 2018;18(14):10407-18. https://doi.org/10.5194/acp-18-10407-2018 https://www.atmos-chem-phys.net/18/10407/2018/.

41. Jacobson MZ. Investigating cloud absorption effects: global absorption properties of black carbon, tar balls, and soil dust in clouds and aerosols. Geophys Res. 2012;117:D6. https://doi.org/10.1029/2011jd017218 https:// agupubs.onlinelibrary.wiley.com/doi/abs/10.1029/2011JD017218.

42. Ghio AJ, Soukup JM, Case M, Dailey LA, Richards J, Berntsen J, et al. Exposure to wood smoke particles produces inflammation in healthy volunteers. Occup Environ Med. 2012;69(3):170-5. https://doi.org/10.1136/ oem.2011.065276 https://oem.bmj.com/content/oemed/69/3/170.full.pdf.

43. Roscioli E, Hamon R, Lester SE, Jersmann HPA, Reynolds PN, Hodge S. Airway epithelial cells exposed to wildfire smoke extract exhibit dysregulated autophagy and barrier dysfunction consistent with COPD. Respir Res. 2018;19(1):234. https://doi.org/10.1186/s12931-018-0945-2.

44. Danielsen PH, Møller P, Jensen KA, Sharma AK, Wallin $H$, Bossi $R$, et al. Oxidative stress, DNA damage, and inflammation induced by ambient air and wood smoke particulate matter in human A549 and THP-1 cell lines. Chem Res Toxicol. 2011;24(2):168-84. https://doi.org/10. 1021/tx100407m

45. Jensen A, Karottki DG, Christensen JM, Bønløkke JH, Sigsgaard T, Glasius M, et al. Biomarkers of oxidative stress and inflammation after wood smoke exposure in a reconstructed Viking age house. Environ Mol Mutagen. 2014; 55(8):652-61. https://doi.org/10.1002/em.21877 https://onlinelibrary.wiley. com/doi/abs/10.1002/em.21877.

46. Dilger M, Orasche J, Zimmermann R, Paur HR, Diabate S, Weiss C. Toxicity of wood smoke particles in human A549 lung epithelial cells: the role of PAHs, soot and zinc. Arch Toxicol. 2016;90(12):3029-44. https://doi.org/10.1007/ s00204-016-1659-1 https://www.ncbinlm.nih.gov/pubmed/26838041.

47. Patel VA, Longacre A, Hsiao K, Fan H, Meng F, Mitchell JE, et al. Apoptotic cells, at all stages of the death process, trigger characteristic signaling events that are divergent from and dominant over those triggered by necrotic cells: implications for the delayed clearance model of autoimmunity. J Biol Chem. 2006;281 (8):4663-70. https://doi.org/10.1074/jbc. M508342200 https://www.ncbi.nlm.nih.gov/pubmed/16377620. https:// www.ncbi.nlm.nih.gov/pmc/articles/PMC3504611/.

48. Poon IKH, Hulett MD, Parish CR. Molecular mechanisms of late apoptotic/ necrotic cell clearance. Cell Death Differ. 2009;17:381. https://doi.org/10. 1038/cdd.2009.195 https://www.nature.com/articles/cdd2009195 \#supplementary-information.

49. Andreau K, Leroux M, Bouharrour A. Health and cellular impacts of air pollutants: from cytoprotection to cytotoxicity. Biochem Res Int. 2012;2012: 493894. https://doi.org/10.1155/2012/493894 https://www.ncbi.nlm.nih.gov/ pubmed/22550588. https://www.ncbi.nlm.nih.gov/pmc/PMC3328890/. 
50. de Oliveira AN, Vessoni AT, Quinet A, Fortunato RS, Kajitani GS, Peixoto MS, et al. Biomass burning in the Amazon region causes DNA damage and cell death in human lung cells. Sci Rep. 2017;7(1):10937. https://doi.org/10.1038/ s41598-017-11024-3 https://www.ncbi.nlm.nih.gov/pubmed/28883446. https://www.ncbi.nlm.nih.gov/pmc/PMC5589902/.

51. Ramos C, Cisneros J, Gonzalez-Avila G, Becerril C, Ruiz V, Montaño M. Increase of matrix Metalloproteinases in Woodsmoke-induced lung emphysema in Guinea pigs. Inhal Toxicol. 2009;21(2):119-32. https://doi.org/ 10.1080/08958370802419145.

52. Lawal AO. Air particulate matter induced oxidative stress and inflammation in cardiovascular disease and atherosclerosis: the role of Nrf2 and AhRmediated pathways. Toxicol Lett. 2017;270:88-95. https://doi.org/10.1016/j. toxlet.2017.01.017 https://www.ncbi.nlm.nih.gov/pubmed/28189649.

53. Gawda A, Majka G, Nowak B, Marcinkiewicz J. Air pollution, oxidative stress, and exacerbation of autoimmune diseases. Cent Eur J Immunol. 2017:42(3): 305-12. https://doi.org/10.5114/ceji.2017.70975 https://www.ncbi.nlm.nih. gov/pubmed/29204097. https://www.ncbi.nlm.nih.gov/pmc/PMC5708213/.

54. Hou L, Zhu Z-Z, Zhang X, Nordio F, Bonzini M, Schwartz J, et al. Airborne particulate matter and mitochondrial damage: a cross-sectional study. Environ Health. 2010;9(1):48. https://doi.org/10.1186/1476-069x-9-48.

55. Wong JYY, Hu W, Downward GS, Seow WJ, Bassig BA, Ji B-T, et al. Personal exposure to fine particulate matter and benzo [a] pyrene from indoor air pollution and leukocyte mitochondrial DNA copy number in rural China. Carcinogenesis. 2017;38(9):893-9. https://doi.org/10.1093/carcin/bgx068 https://www.ncbi.nlm.nih.gov/pubmed/28911003. https://www.ncbi.nlm.nih. gov/pmc/PMC5862333/.

56. Chan LK, Nguyen KQ, Karim N, Yang Y, Rice RH, He G, et al. Relationship between the molecular composition, visible light absorption, and healthrelated properties of smoldering woodsmoke aerosols. Atmos Chem Phys Discuss. 2019;2019:1-29. https://doi.org/10.5194/acp-2019-751 https://www. atmos-chem-phys-discuss.net/acp-2019-751/.

57. Pardo M, Melendez JA, Tirosh O. Manganese superoxide dismutase inactivation during Fas (CD95)-mediated apoptosis in Jurkat T cells. Free Radic Biol Med. 2006:41(12):1795-806. https://doi.org/10.1016/j.freeradbiomed.2006.08.027 https:/www.ncbi.n/m.nih.gov/pubmed/17157182

58. Shishido S, Koga H, Harada M, Kumemura H, Hanada S, Taniguchi E, et al. Hydrogen peroxide overproduction in megamitochondria of troglitazonetreated human hepatocytes. Hepatology. 2003;37(1):136-47. https://doi.org/ 10.1053/jhep.2003.50014 https://www.ncbi.nlm.nih.gov/pubmed/12500198.

59. Cheng G, Zielonka M, Dranka B, Kumar SN, Myers CR, Bennett B, et al. Detection of mitochondria-generated reactive oxygen species in cells using multiple probes and methods: potentials, pitfalls, and the future. J Biol Chem. 2018;293(26):10363-80. https://doi.org/10.1074/jbc. RA118.003044 https://www.ncbi.nlm.nih.gov/pubmed/29739855.

60. Zhao H, Kalivendi S, Zhang H, Joseph J, Nithipatikom K, Vasquez-Vivar J, et al. Superoxide reacts with hydroethidine but forms a fluorescent product that is distinctly different from ethidium: potential implications in intracellular fluorescence detection of superoxide. Free Radic Biol Med. 2003;34(11):1359-68 https://www.ncbi.nlm.nih.gov/pubmed/12757846.

61. LeBel CP, Ischiropoulos H, Bondy SC. Evaluation of the probe 2',7'dichlorofluorescin as an indicator of reactive oxygen species formation and oxidative stress. Chem Res Toxicol. 1992;5(2):227-31 https://www.ncbi.nlm. nih.gov/pubmed/1322737.

62. Rooney JP, Ryde IT, Sanders LH, Howlett EH, Colton MD, Germ KE, et al. PCR based determination of mitochondrial DNA copy number in multiple species. Methods Mol Biol. 2015;1241:23-38. https://doi.org/10.1007/978-14939-1875-1_3 http://www.ncbi.nlm.nih.gov/pmc/articles/PMC4312664/.

\section{Publisher's Note}

Springer Nature remains neutral with regard to jurisdictional claims in published maps and institutional affiliations.

\section{Ready to submit your research? Choose BMC and benefit from:}

- fast, convenient online submission

- thorough peer review by experienced researchers in your field

- rapid publication on acceptance

- support for research data, including large and complex data types

- gold Open Access which fosters wider collaboration and increased citations

- maximum visibility for your research: over $100 \mathrm{M}$ website views per year

At $\mathrm{BMC}$, research is always in progress.

Learn more biomedcentral.com/submissions 